TECHNICAL TRANSACTIONS 8/2019

MECHANICS

DOI: $10.4467 / 2353737$ XCT.19.087.10866 SUBMISSION OF THE FINAL VERSION: $3 / 08 / 2019$

\author{
Łukasz Ślusarczyk (D) orcid.org/0000-0002-3565-7868 \\ slusarczyk@mech.pk.edu.pl \\ Emilia Franczyk \\ Institute of Production Engineering, Faculty of Mechanical Engineering, Cracow \\ University of Technology
}

\title{
AN ANALYSIS OF FAST-CHANGING PHENOMENA IN THE CUTTING ZONE DURING THE TURNING OF A TI-6AL-4V TITANIUM ALLOY SHAFT
}

ANALIZA ZJAWISK SZYBKOZMIENNYCH W STREFIE SKRAWANIA PODCZAS

TOCZENIA WAŁKA ZE STOPU TYTANU TI-6AL-4V

\begin{abstract}
This paper presents an experimental method of determining the velocity of chip flow on the rake surface of a cutting insert during the longitudinal turning of Ti-6Al-4V titanium alloy. A Seco CNMG120408-M1 833 carbide cutting insert without a protective coating was used for the purposes of research. In order to record phenomena in the cutting zone, a PHANTOM V5.2 high-speed camera was used and placed above the area of machining. The camera recorded the process at a speed of $3000 \mathrm{fps}$. Placing the camera near the cutting zone allowed recording the process of chip formation and its flow along the rake face of the insert. Trials of longitudinal turning were performed in accordance with the test plan, where $\mathrm{v}_{c}$ and $\mathrm{f}$ were the independent variables. In addition, the tests were performed for two different cutting depths. Processing and analysis of the obtained video sequences were performed with the use of CineViewer 663 and Tracker computer applications. Experimental determination of the velocity of chip flow at the rake face of a cutting insert was conducted by analysing the movement of the characteristic point on the outside side of the chip. Analysis of variance for the obtained results was performed using ANOVA and the regression functions were determined.
\end{abstract}

Keywords: Ti-6Al-4V, fast-changing phenomena, ANOVA

\section{Streszczenie}

W artykule przedstawiono eksperymentalny sposób wyznaczania prędkości spływu wióra po powierzchni natarcia plytki skrawającej podczas toczenia wzdłużnego stopu tytanu Ti-6Al-4V. W ramach badań wykorzystano płytkę skrawającą z węglika spiekanego, bez powłoki ochronnej, Seco CNMG120408-M1 833. Do rejestracji zjawisk w strefie skrawania zastosowano kamerę szybkoklatkową PHANTOM V5.2 umieszczoną nad strefą obróbki. Szybkość rejestracji kamery wynosiła $3000 \mathrm{kl} / \mathrm{s}$. Ustawienie kamery w tym miejscu umożliwiało rejestrację procesu powstawania i splywu wióra po powierzchni natarcia plytki. Próby toczenia wzdłużnego realizowano zgodnie z przyjętym planem badań, gdzie zmiennymi niezależnymi byly $v_{c}$ if. Dodatkowo próby wykonano dla dwóch różnych glębokości skrawania. Obróbkę i analizę otrzymanych sekwencji wideo przeprowadzono w aplikacjach komputerowych CineViewer 663 oraz Tracker. Eksperymentalne wyznaczenia prędkości spływu wióra na powierzchni natarcia płytki skrawającej realizowano przez analizę ruchu punktu charakterystycznego na zewnętrznej stronie wióra. Dla uzyskanych wyników przeprowadzono analizę wariancji ANOVA i wyznaczono funkcje regresji.

Słowa kluczowe: Ti-6Al-4V, zjawiska szybkozmienne, ANOVA 


\section{Introduction}

Machining is one of the most common techniques for manufacturing parts of machines and devices. At present, in addition to meeting high requirements with regard to dimensional and shape accuracy of objects made, great attention is paid to achieving high levels of production efficiency. When using CNC machines, the proper selection of cutting parameters is a very important factor that allows the achievement of high production efficiency $[1,2]$. In the automotive and aerospace industries, titanium and its alloys are commonly used materials. Due to its low coefficient of thermal conductivity and a tendency to cure under the influence of heat (precipitation hardening), titanium belongs to the group of difficult-to-cut materials. A lot of space in literature is devoted to the analysis of physical phenomena that occur in the cutting zone when machining these materials $[3,4]$. Such phenomena have an impact on the form of the chip generated during machining [5-8, 10]. This article focuses on issues related to the process of creating and shaping the chip. Both the conditions in which the formation of chips occurs and their form have a significant impact on the safety, reliability and efficiency of the cutting process as well as on the features of the surface layer of the processed workpiece. Analysis of the process of chip formation is a complex issue. This is mainly related to the variable area of contact between the chip and the tool. Rapid development in the field of chip breaking is associated with dynamic progress in the construction of indexable inserts [5-8]. Manufacturers of cutting tools are increasingly devoting significant funds to research aimed at improving the design and specialisation of tools $[3,9,11]$. Currently, great attention is being paid to the implementation of new, specially shaped chip breakers. Modern solutions are aimed at forcing the chip to be directed to the untreated surface of the workpiece or towards the flank surface of the tool in such a way that it has a desired shape and breaks down quickly.

\section{Conducted research}

Laboratory tests consisted of the longitudinal turning of a shaft made of Ti-6Al-4V titanium alloy. The diameter of the shaft was $\mathrm{D}=60 \mathrm{~mm}$. The test stand comprised a Knuth Masterturn 400 lathe, a Phantom v5.2 high-speed camera placed above the cutting zone, a Dedocool spot illumination system, and a computer with Cine 663 software. The cutting tool was mounted in a single-position tool post (Fig. 1). 


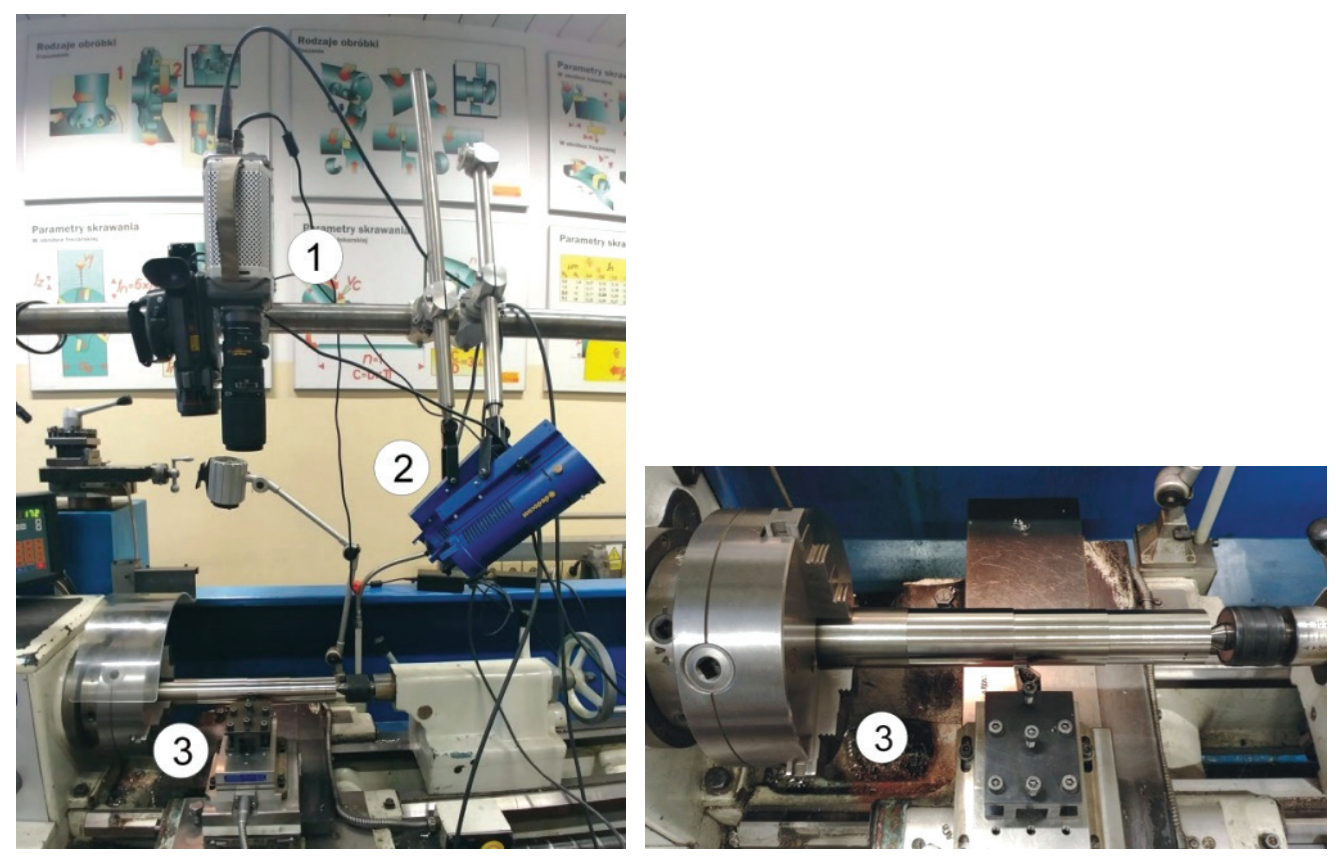

Fig. 1. The test stand: 1 - Phantom v5.2 high-speed camera placed in front of the cutting zone, 2 - spot illumination system Dedocool, 3 - tool position in relation to the workpiece

Table 1 presents the configuration parameters of the PHANTOM v 5.2 high-speed camera.

Table 1. The configuration parameters of the PHANTOM v 5.2 high-speed camera

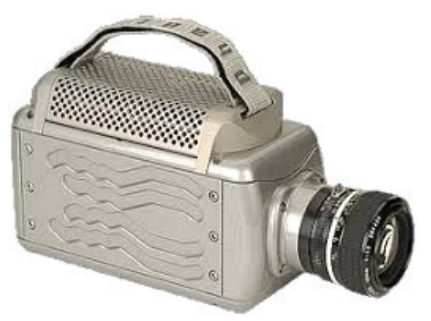

\begin{tabular}{|c|c|}
\hline resolution & $512 \times 512-8 \mathrm{bit}$ \\
\hline sensor & $\mathrm{CMOS}$ \\
\hline frame rate & $3000 \mathrm{fps}$ \\
\hline memory & $4 \mathrm{~GB}$ \\
\hline distance measurement & $1.0 \mathrm{~m}$ \\
\hline
\end{tabular}

Figure 2 shows a NIKKOR $200 \mathrm{~mm}$ prime lens which was used to record the fast-changing images. Figure 3 presents the Dedocool spot illumination system, model Coolt3.

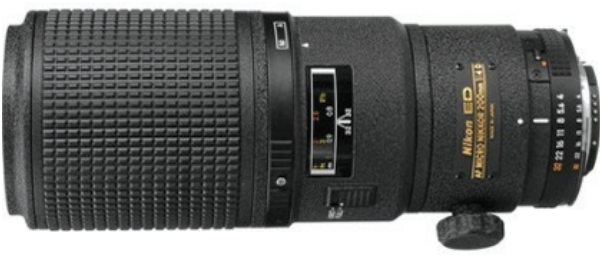

Fig. 2. NIKON Nikkor AF Micro $200 \mathrm{~mm}$ f/4D
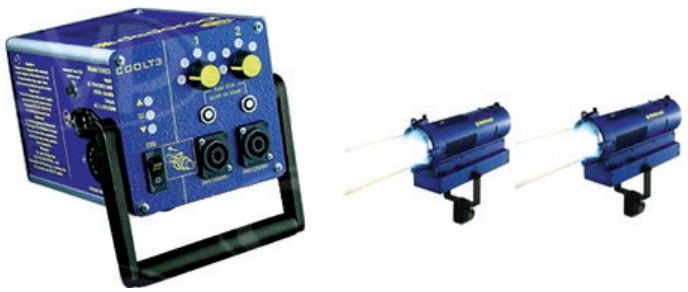

Fig. 3. Dedocool spot illumination system, model Coolt 3 
The chemical composition of Ti-6Al-4V titanium alloy is shown in Table 2.

Table 2. Chemical composition of Ti-6Al-4V titanium alloy

\begin{tabular}{|c|c|c|c|c|c|c|c|}
\hline Al. [\%] & $\mathbf{V}[\%]$ & $\mathbf{F e}[\%]$ & $\mathbf{O}[\%]$ & $\mathbf{C}[\%]$ & $\mathbf{N}[\%]$ & $\mathbf{H}[\%]$ & $\mathbf{T i}$ \\
\hline $\min 5.50$ & $\min 3.50$ & & & & & & \\
$\max 6.75$ & $\max 4.50$ & $\max 4.50$ & $\max 4.50$ & $\max 4.50$ & $\max 4.50$ & $\max 4.50$ & rest \\
\hline
\end{tabular}

The tool that was used during the trials was a SECO turning tool consisting of a non-coated carbide insert, marked as CNMG120408-M1 833 and a DCLNR2525M12-M tool holder. The geometric parameters of the cutting insert used are shown in Table 3.

Table 3. Geometric parameters of the cutting insert used

\begin{tabular}{|l|c|c|c|c|}
\hline \multirow{2}{*}{} & Name & Description & Value \\
\cline { 3 - 5 } & $\mathrm{D} 1$ & $\begin{array}{c}\text { fixing hole } \\
\text { diameter }\end{array}$ & $5.2 \mathrm{~mm}$ \\
\cline { 3 - 5 } & EPSR & insert angle & $80^{\circ}$ \\
\cline { 3 - 5 } & $\mathrm{IC}$ & $\begin{array}{c}\text { inscribed circle } \\
\text { diameter }\end{array}$ & $12.7 \mathrm{~mm}$ \\
\cline { 3 - 5 } & $\mathrm{L}$ & $\begin{array}{c}\text { theoretical } \\
\text { cutting edge } \\
\text { length }\end{array}$ & $12.9 \mathrm{~mm}$ \\
\hline & $\mathrm{RE}$ & corner radius & $0.8 \mathrm{~mm}$ \\
\hline & $\mathrm{S}$ & insert thickness & $4.76 \mathrm{~mm}$ \\
\hline
\end{tabular}

The profiles of the rake surface of the insert used are presented below; these are measured in the tool coordinate system at distances of 1.25 and $2.5 \mathrm{~mm}$ from its top (Fig. 4a). The measurement was made on a Taylor Hobson Intra 50 digital profilograph. The values of rake angles were determined at a distance of $0.4 \mathrm{~mm}$ from the cutting edge for the obtained cross sections (Fig. 4b).

a)

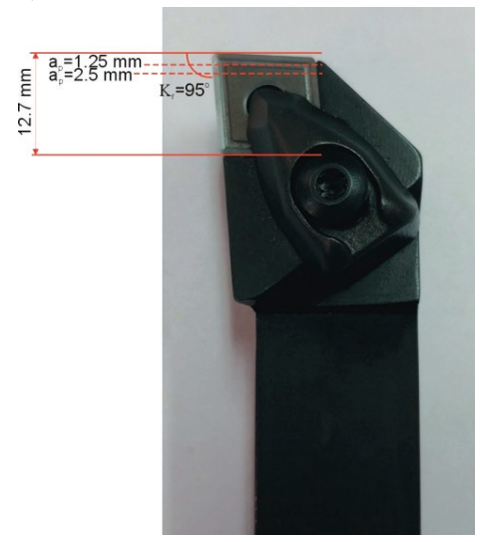

b)

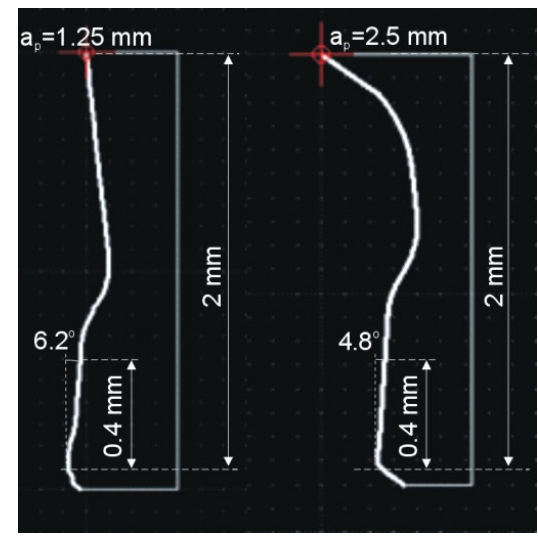

Fig. 4. Rake surface profiles measured at cut depths of $a_{p}=1.25 \mathrm{~mm}$ and $a_{p}=2.5 \mathrm{~mm}$ 


\section{Findings}

The research plan was based on an L9 orthogonal table; there were two independent factors, each with three different values. The independent factors in the tests were: $v_{c}-$ cutting speed, $f$ - feed. Parameters $v_{c}$ and $f$ were assumed respectively as independent variables $A$ and $B$. The ranges of variation of the cutting parameters were determined on the basis of catalogue data. Table 4 presents the assumed values of the cutting parameters.

Table 4. Values of cutting parameters

\begin{tabular}{|c|c|c|c|c|}
\hline Symbol & Cutting parameters & \multicolumn{3}{|c|}{ Parameter values } \\
\hline $\mathrm{A}$ & $v_{c}[\mathrm{~m} / \mathrm{min}]$ & 18 & 25 & 32 \\
\hline \multicolumn{2}{|c|}{$\begin{array}{c}\mathrm{B} \\
\end{array}$} & 0.153 & 0.230 & 0.307 \\
\hline
\end{tabular}

The parameter values for the individual trials are given in the table below (Table 5).

Table 5. The parameter values for individual trials

\begin{tabular}{|c|c|c|c|c|}
\hline Test no. & A & B & $\boldsymbol{v}_{c}[\mathbf{m} / \mathbf{m i n}]$ & $\mathbf{f}[\mathbf{m m} / \mathbf{r e v}]$ \\
\hline 1 & 1 & 1 & 18 & 0.153 \\
\hline 2 & 1 & 2 & 18 & 0.230 \\
\hline 3 & 1 & 3 & 18 & 0.307 \\
\hline 4 & 2 & 1 & 25 & 0.153 \\
\hline 5 & 2 & 2 & 25 & 0.230 \\
\hline 6 & 2 & 3 & 25 & 0.307 \\
\hline 7 & 3 & 1 & 32 & 0.153 \\
\hline 8 & 3 & 2 & 32 & 0.307 \\
\hline 9 & 3 & 3 & 32 & \\
\hline
\end{tabular}

A series of longitudinal turning operations was additionally performed for two cutting depth values: $a_{p}=1.25$ and $2.5 \mathrm{~mm}$. Every turning operation was recorded using a high-speed camera. A Phantom high speed camera with a Nikon $200 \mathrm{~mm}$ lens was used to record the process of chip formation. The recording duration was $4 \mathrm{~s}$ with a of $3000 \mathrm{fps}$, and a resolution of 512 x 512 px. Several-frame fragments were extracted from the recorded sequences with a use of Cine software. Presented below are examples of analyses obtained for: trial no. $1\left(a_{p}=1.25 \mathrm{~mm}, v_{c}=18 \mathrm{~m} / \mathrm{min}, f=0.153 \mathrm{~mm} / \mathrm{rev}\right)$ - Fig. 5 ; trial no. 3 $\left(a_{p}=2.5 \mathrm{~mm}, v_{c}=18 \mathrm{~m} / \mathrm{min}, f=0.307 \mathrm{~mm} / \mathrm{rev}\right)$ - Fig. 6. The different forms of chips obtained for different feed values are visible. 

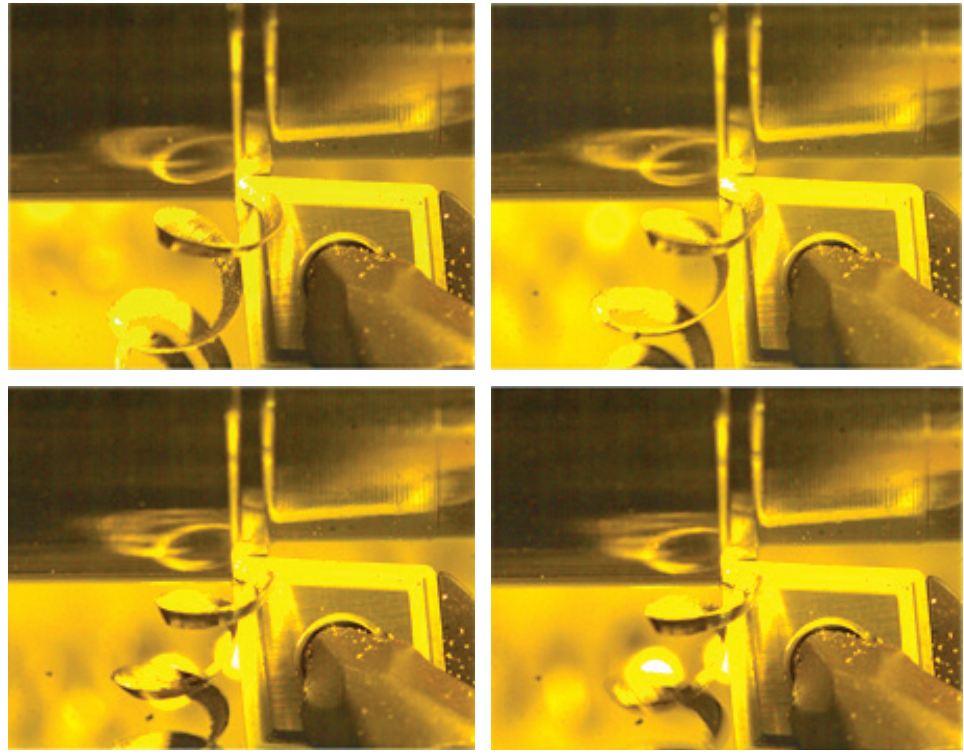

Fig. 5. Example images from trial no. 1
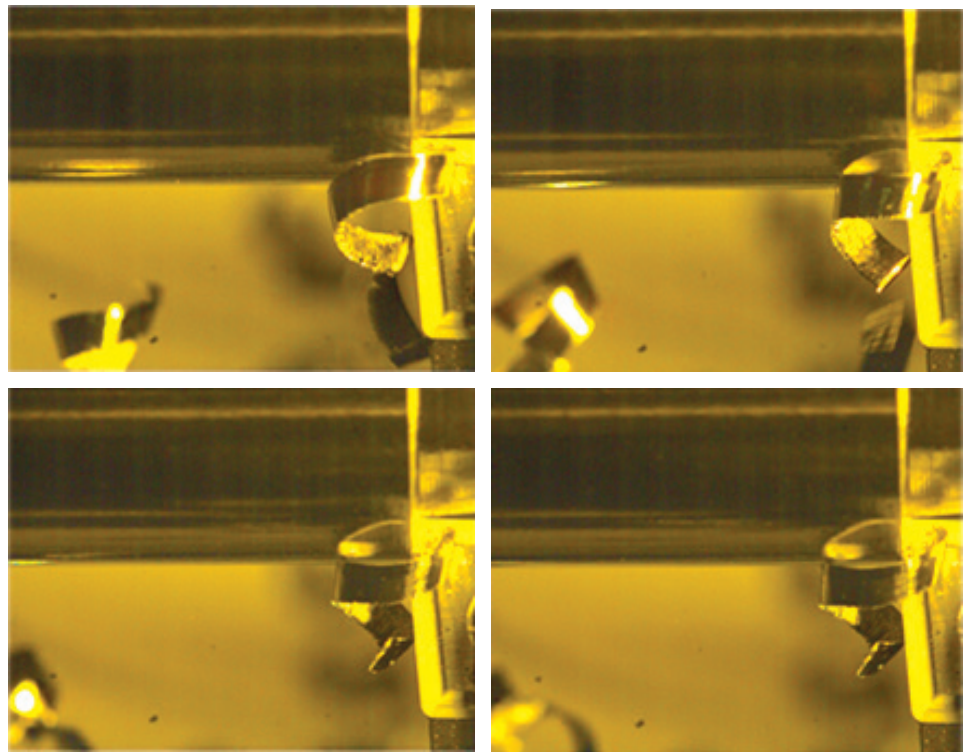

Fig. 6. Example images from trial no. 3

It was important to ensure that the selected video sequence was not overexposed, and that the chip flowing down the rake surface had a specific point that could be used as a marker in the analysis process. In practice, it was difficult to indicate specific points on the flowing chips for individual trials; this was related to the reflection of light from the surface of the chip. Filters were a helpful tool for eliminating this issue. An example of the use of filters in the CineViewer663 software is shown below (Fig. 7). 

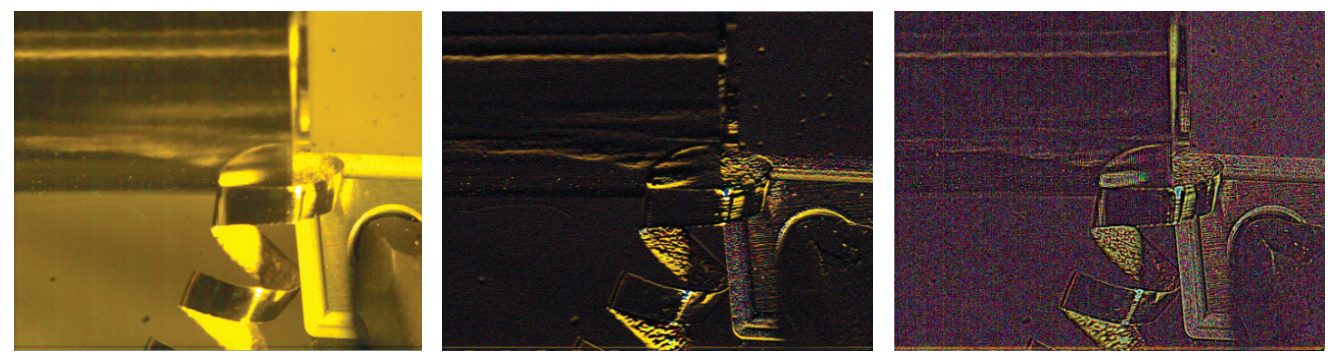

Fig. 7. Example use of filters in the CineViewer 663

Following the procedure outlined above, Tracker software was used; this enables the analysis of the movement of a given point. By using the 'Point Mass' tool, and based on the time-lapse analysis of the position of the specific point on the chip, average velocities with which the chip floats on the face of the tool's rake were determined (Figs. 8 and 9). It should be noted that in order to determine the average velocity of flowing chips accurately, it was necessary to specify the reference dimension in the analysed photographs each time. Such a dimension was the length of the working part of the tool.

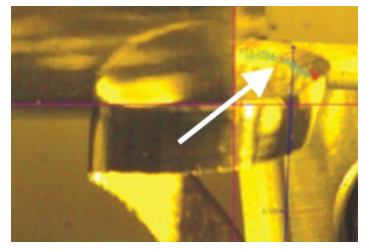

Fig. 8. Analysis

of the position of the specific point on the chip

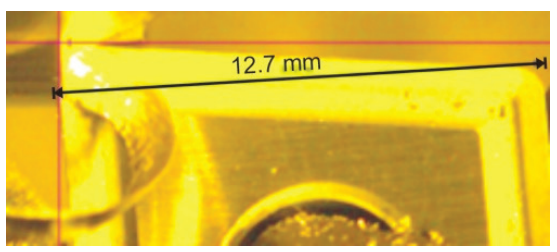

Fig. 9. The reference dimension in the analysed photographs

By analysing the movement of the specific point on the chip, the average velocity of its flow on the rake face of an insert $v_{c h}[\mathrm{~m} / \mathrm{min}]$ was determined. The obtained values of the chip flow velocity, determined for two cutting depths, are listed below in Table 6.

Table 6. Obtained values of the chip flow velocity determined for two cutting depths

\begin{tabular}{|c|c|c|c|c|c|c|}
\hline \multirow{2}{*}{ Test no. } & \multirow{2}{*}{$\mathbf{A}$} & \multirow{2}{*}{ B } & \multirow{2}{*}{$\begin{array}{c}v_{c} \\
{[\mathbf{m} / \mathbf{m i n}]}\end{array}$} & \multirow{2}{*}{$\begin{array}{c}f \\
{[\mathrm{~mm} / \mathbf{r e v}]}\end{array}$} & $a_{p}=1.25 \mathrm{~mm}$ & $a_{p}=2.5 \mathrm{~mm}$ \\
\hline & & & & & \multicolumn{2}{|c|}{$v_{c h}[\mathrm{~m} / \mathrm{min}]$} \\
\hline 1 & 1 & 1 & 18 & 0.153 & 16.5 & 12.4 \\
\hline 2 & 1 & 2 & 18 & 0.230 & 15.1 & 14.7 \\
\hline 3 & 1 & 3 & 18 & 0.307 & 18.0 & 13.1 \\
\hline 4 & 2 & 1 & 25 & 0.153 & 18.6 & 18.2 \\
\hline 5 & 2 & 2 & 25 & 0.230 & 16.8 & 19.3 \\
\hline 6 & 2 & 3 & 25 & 0.307 & 19.6 & 15.3 \\
\hline 7 & 3 & 1 & 32 & 0.153 & 22.8 & 22.2 \\
\hline 8 & 3 & 2 & 32 & 0.230 & 27.0 & 22.0 \\
\hline 9 & 3 & 3 & 32 & 0.307 & 28.6 & 26.8 \\
\hline
\end{tabular}


Figures 10 and 11 show the influence of the particular cutting data on the values of average chip flow velocity.

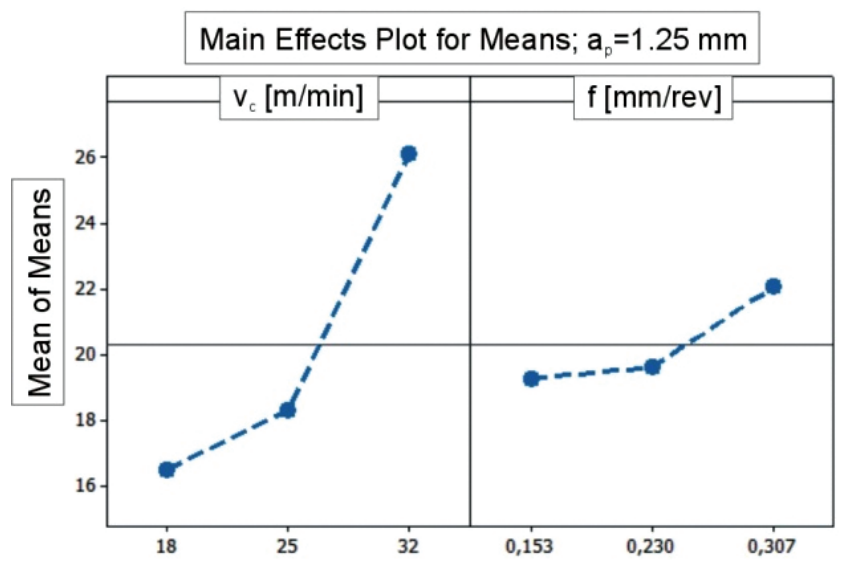

Fig. 10. The influence of the cutting data on the values of the average chip flow velocity $\left(a_{p}=1.25 \mathrm{~mm}\right)$

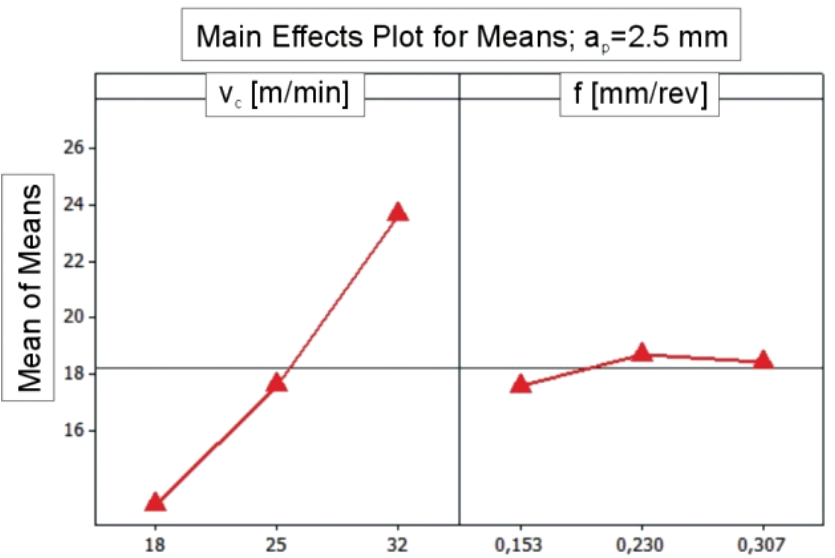

Fig. 11. The influence of the cutting data on the values of the average chip flow velocity $\left(a_{p}=2.5 \mathrm{~mm}\right)$

Tables 7 and 8 present the statistical analysis of the test results (DF - degrees of freedom, Seq SS - sums of squares, Adj SS - adjusted sums of squares, Adj MS - adjusted means squares).

Table 7. Analysis of variance for average value $v_{c h}, a_{p}=1.25 \mathrm{~mm}$

\begin{tabular}{|c|c|c|c|c|c|c|}
\hline Source & DF & Seq SS & Adj SS & Adj MS & F & p \\
\hline$f$ & 1 & 11.514 & 11.514 & 11.514 & 2.112 & 0.196 \\
\hline$v_{c}$ & 1 & 138.071 & 138.071 & 138.071 & 25.329 & 0.002 \\
\hline residual error & 6 & 32.707 & 32.707 & 5.451 & & \\
\hline total & 8 & 182.292 & & & & \\
\hline
\end{tabular}


Table 8. Analysis of variance for average value $v_{c h}, a_{p}=2.5 \mathrm{~mm}$

\begin{tabular}{|c|c|c|c|c|c|c|}
\hline Source & DF & Seq SS & Adj SS & Adj MS & F & p \\
\hline$f$ & 1 & 0.954 & 0.954 & 0.954 & 0.212 & 0.661 \\
\hline$v_{c}$ & 1 & 157.202 & 157.202 & 157.202 & 35.016 & 0.001 \\
\hline residual error & 6 & 26.936 & 26.936 & 4.489 & & \\
\hline total & 8 & 185.092 & & & & \\
\hline
\end{tabular}

Equations $v_{c h}\left(f, v_{c}\right)$ for $a_{p}=1.25 \mathrm{~mm}($ eq. 1$)$ and $a_{p}=2.5 \mathrm{~mm}$ (eq. 2$)$ are described below:

$$
\begin{gathered}
v_{c h}(f, v c)=-0.938755+17.9908 \cdot f+0.685295 \cdot v_{c} \\
v_{c h}=-1.24343+5.17868 \cdot f+0.731232 \cdot v_{c}
\end{gathered}
$$

\section{Conclusions}

The research involved recording, in the form of video sequences, the process of chip formation and its flow on the rake surface of a cutting insert during the longitudinal turning of Ti-6Al-4V titanium alloy. A PHANTOM V5.2 high-speed camera was used for this purpose. Tests were performed in accordance with the adopted test plan. Video sequences were recorded at $3000 \mathrm{fps}$. Using the CineViewer 663 software, relevant fragments were selected for further analysis. In the subsequent part of the work, the average velocities of chip flow on the rake surface were determined with a use of Tracker software. For the obtained results an ANOVA was conducted and the $v_{c h}$ regression equations $\left(f, v_{c}\right)$ were determined. On the basis of the results, a strong influence of the cutting speed on the chip flow velocity was found for two examined depths of cut: $a_{p}=1.25 \mathrm{~mm}$ and $a_{p}=2.5 \mathrm{~mm}$. An increase in the cutting speed results in an increase in the velocity of chip flow.

An increase in feed rate had a much smaller impact on the increase in the value of the chip flow velocity than cutting speed. It was found that slightly higher values of chip flow velocity occur for a smaller depth of cut. This phenomenon may result from the fact that depending on the depth of cut there are various shapes of chip breaker. In the case of a smaller depth of cut, the chip had a continuous form in the shape of a ribbon and it did not break. For $a_{p}=2.5 \mathrm{~mm}$, the chip was broken into sections by the insert's rake face and had the a shape of an arc. 


\section{References}

[1] Benardos P.G., Vosniakos G.C., Predicting surface roughness in machining: a review, International Journal of Machine Tools and Manufacture 43(8), 2003, 833-844.

[2] Chauvy P.F., Madore C., Landolt D., Variable length scale analysis of surface topography: characterization of titanium surfaces for biomedical applications, Surface and Coatings Technology 110, 1998, 48-56.

[3] Davies M.A., Chou Y., Evans C.J., On Chip Morphology, Tool Wear and Cutting Mechanics in Finish Hard Turning, CIRP Annals - Manufacturing Technology 45(1), 1996, 77-82.

[4] Haglund A.J., Kishawy H.A., Rogers R.J., An Exploration of Friction Models for the ChipTool Interface Using an Arbitrary Lagrangian-Eulerian Finite Element Model, Wear 265, 452-460 (2008).

[5] Shamoto E., Aoki T., Sencer B., Suzuki N., Hino R., Koide T., Control of chip flow with guide grooves for continuous chip disposal and chip-pulling turning, CIRP Annals Manufacturing Technology 60(1), 2011, 125-128.

[6] Shaw M.C., Vyas A., The Mechanism of Chip Formation with Hard Turning Steel, CIRP Annals - Manufacturing Technology 47(1), 1998, 77-82.

[7] Słodki B., Struzikiewicz G., Ślusarczyk L., Influence of cutting fluid conditions and cutting parameters on the chip form in turning of titanium and steel alloys, Key Engineering Materials 686, 2016, 74-79.

[8] Struzikiewicz G., The application of high-speed camera for analysis of chip creation process during the steel turning, Proc. of SPIE 10031, 2016, 1-8.

[9] Struzikiewicz G., Zębla W., Rumian K., Application of Taguchi method to optimization of cutting force and temperature during turning of difficult to cut materials, Key Engineering Materials 686, 2016, 114-118.

[10] Ślusarczyk Ł., Franczyk E., Development and verification of a measuring stand for recording the physical phenomena during turning, Photonics Applications in Astronomy Communications Industry and High-Energy Physics Experiments Book Proc. of SPIE 10445, 104456G, 2017.

[11] Ślusarczyk Ł., Franczyk E., Experimental determination of forces in a cutting zone during turning a stainless steel shaft, Czasopismo Techniczne 5-M/2018.

If you want to quote this article, its proper bibliographic entry is as follow: Ślusarczyk Ł., Franczyk E., An analysis of fast- 